\title{
281. Experimentelle Untersuchungen mit einem Gerät zur kombinierten Respirator- und elektrisch stimulierten Zwerchfellatmung
}

\author{
J. Holle*, M. Baum, H. Benzer, E. Moritz \\ und H. Thомa-Wien/Österreich
}

Experimental Investigations with a Device for Combined Respirator and Electrically Stimulated Diaphragmatic Respiration

Summary. A combined method of respirator ventilation and electrically stimulated diaphragm ventilation is discussed. A regulating device has been developed which ensures synchronous action of respirator stimulation and actual electrical stimulation by delaying the electrical impulses on the one hand and on the other hand by data of various parameters. The effect of diaphragm stimulation is measured by a mechanical-electrical transformer. With the aid of the device the effect of the combination of respirator ventilation and electrically stimulated diaphragm ventilation on lung function and on the pulmonary circulation was examined in animal experiments. The results are discussed systematically on the basis of the data obtained.

Zusammenfassung. Es wird die Methode zur Kombination von Respiratorbeatmung und elektrisch stimulierter Zwerchfellbeatmung besprochen. Dafür wurde ein Steuergerät entwickelt, welches einerseits durch Zeitverzögerung der elektrischen Impulse, andererseits durch Kennwerte mehrerer Parameter den synchronen Betrieb von Respirator- und der eigentlichen elektrischen Stimulation gewährleistet.

Der Effekt der Zwerchfellstimulation wird über einen mechanisch-elektrischen Umsetzer gemessen.

Unter Verwendung dieses Gerätes wurde tierexperimentell der Effekt der Kombination von Respirator- und elektrisch stimulierter Zwerchfellbeatmung auf die Lungenfunktion und den Lungenkreislauf untersucht.

Die Ergebnisse werden anhand der erhobenen Meßwerte systematisch diskutiert.

\section{Aminosäuren-Bestimmung im Serum bei der parenteralen Ernährung Schwerkranker}

\author{
J. Schulte Am Esch*, J. Breuer und M. Dohmen-Bonn
}

\author{
Amino-Acid Estimations in the Serum in Parenteral Feeding \\ of the Seriously Ill
}

Summary. In 16 seriously ill patients (8 with multiple injuries and 8 after gastrointestinal resections with other complicating conditions) the amino-acids in the serum were estimated on 4 successive days in ion exchange columns with the aid of chromatography. On the first day blood specimens for amino-acid estimation were taken as controls. This was followed by infusion of $500 \mathrm{ml}$ of a $10 \%$ fat emulsion. After a control analysis at the start of the second day 1 litre of an amino-acid 